\title{
Thalassomonas agarivorans sp. nov., a marine agarolytic bacterium isolated from shallow coastal water of An-Ping Harbour, Taiwan, and emended description of the genus Thalassomonas
}

Correspondence Wung Yang Shieh winyang@ntu.edu.tw

\author{
Wen Dar Jean, ${ }^{1}$ Wung Yang Shieh ${ }^{2}$ and Tung Yen Liu ${ }^{2}$ \\ ${ }^{1}$ Center for General Education, Leader University, No. 188, Sec. 5, An-Chung Rd, Tainan, \\ Taiwan \\ ${ }^{2}$ Institute of Oceanography, National Taiwan University, PO Box 23-13, Taipei, Taiwan
}

Alteromonas-like bacteria in the class Gammaproteobacteria comprise a large group of marine, heterotrophic, polarflagellated, Gram-negative rods that are mainly nonfermentative aerobes. They are readily isolated from various marine sources and probably represent a major component of the microbial biota in the sea. The similarity of phenotypic characteristics has made it difficult to differentiate these bacteria at the species level or even at the genus level. However, a phylogenetic study based on 16S rRNA gene sequences classified these bacteria into a variety of families and genera, including Alteromonadaceae (Alteromonas and Glaciecola), Pseudoalteromonadaceae (Pseudoalteromonas and Algicola), Colwelliaceae (Colwellia and Thalassomonas), Ferrimonadaceae (Ferrimonas), Idiomarinaceae (Idiomarina), Moritellaceae (Moritella), Shewanellaceae (Shewanella), Psychromonadaceae (Psychromonas), Oceanimonas and Oceanisphaera (Ivanova et al., 2004); taxonomic affiliation of Oceanimonas and Oceanisphaera at the family level remained undetermined.

Agar, a complex polysaccharide extracted from marine red algae, is widely employed as a gelling agent for microbiological culture media. This refractory material is attacked by relatively few bacterial species (Holt et al., 1994). Agarolytic bacteria are ubiquitous in coastal and estuarine regions;

The GenBank/EMBL/DDBJ accession number for the 16S rRNA gene sequence of strain TMA $1^{\top}$ is DO2 12914. however, they are not exclusively autochthonous in the marine environment, since some reports have shown that they also occur in freshwater, sewage and soil (Agbo \& Moss, 1979; van der Meulen et al., 1974; von Hofsten \& Malmqvist, 1975). Several marine agarolytic strains of Vibrio-like species have been demonstrated to be capable of fixing $\mathrm{N}_{2}$ for anaerobic growth using agar as the sole source of carbon and energy (Shieh et al., 1988). A Vibrio species, Vibrio agarivorans, is also reported to be capable of decomposing agar in addition to these unnamed, Vibrio-like agarolytic strains (Macián et al., 2001b). Alterococcus agarolyticus, the only thermophilic agarolytic species, is a marine, facultatively anaerobic, fermentative, Gram-negative coccus growing between 38 and $58^{\circ} \mathrm{C}$ with optimum growth at about $48^{\circ} \mathrm{C}$ (Shieh \& Jean, 1998). No other agarolytic bacteria have been reported to grow at temperatures of $45^{\circ} \mathrm{C}$ or higher. Only a handful of species belonging to the Alteromonas-like Gammaproteobacteria such as Pseudoalteromonas atlantica (Akagawa-Matsushita et al., 1992; Gauthier et al., 1995), Pseudoalteromonas agarivorans (Romanenko et al., 2003a), Glaciecola mesophila (Romanenko et al., 2003b) and Shewanella olleyana (Skerratt et al., 2002) are agarolytic or weakly agarolytic. Recently, strain JAMB-A33, an agarolytic bacterium which produces a novel $\alpha$-agarase, was isolated from the sediment off Noma Point, Japan (Ohta et al., 2005). Phylogenetic analysis of 16S rRNA gene sequences suggested that this isolate might represent a novel species of Thalassomonas in the Alteromonas-like Gammaproteobacteria. 
However, classification of this isolate on the basis of phenotypic and chemotaxonomic features was not reported (Ohta et al., 2005). Evidence is presented here that an agarolytic bacterium isolated in this laboratory can be classified in a novel species in the genus Thalassomonas.

An-Ping Harbour of Tainan is a small harbour located on the south-west coast of Taiwan. A seawater sample collected from the shallow water region of this harbour was decimally diluted with sterile $\mathrm{NaCl} /$ Tris buffer $(30 \mathrm{~g} \mathrm{NaCl}$ and $0.24 \mathrm{~g}$ Tris in $1 \mathrm{l}$ deionized water, $\mathrm{pH} 8 \cdot 0)$. Aliquots $(0 \cdot 1 \mathrm{ml})$ of the decimal dilutions $\left(10^{2}-10^{4}\right.$ times) were spread on PY (Polypepton/yeast extract) plate medium (Shieh et al., 2000). The plates were incubated at $25^{\circ} \mathrm{C}$ in the dark for 7 days under aerobic conditions. Strain TMA1 ${ }^{\mathrm{T}}$, appearing as an agarolytic off-white colony, was isolated from one of the plates and subsequently purified by successive streaking on PY plates. Its maintenance in our laboratory was performed repeatedly at an interval of 2-3 months by inoculating early stationary phase cultures grown in PY broth into $7 / 10$-strength seawater at a ratio of $2: 50(\mathrm{v} / \mathrm{v})$. Maintenance cultures were kept at $20^{\circ} \mathrm{C}$. The isolate has also been deposited in both JCM and BCRC by lyophilization.

Strain TMA1 ${ }^{\mathrm{T}}$ was cultivated aerobically in PY broth at $25^{\circ} \mathrm{C}$ in the dark for 3 days. Cells were harvested by centrifugation. Total genomic DNA was extracted and purified from the cells by using a Puregene DNA isolation kit (Gentra Systems) in accordance with the manufacturer's instructions. Hydration solution of the purified DNA sample was prepared at concentrations of $500 \mu \mathrm{g} \mathrm{ml}^{-1}$. The DNA hydration solution was used for PCR amplification (Jean et al., 2006).

Sequencing of the 16S rRNA gene sample, alignment and comparison of the resulting sequence and reference sequences available in the GenBank database, calculation of distance matrices for the aligned sequences and reconstruction of a phylogenetic tree by the neighbour-joining method were carried out as described by Shieh et al. (2004). Phylogenetic trees were also reconstructed by using maximum-parsimony (Fitch, 1971) and maximum-likelihood (Felsenstein, 1981) methods. The accession numbers for the sequences used to reconstruct the phylogenetic tree are shown in Fig. 1. Bootstrap confidence values (Felsenstein, 1985) were obtained with 1000 resamplings with an option of stepwise addition.

Fatty acids in whole cells grown on PY plate medium at $25^{\circ} \mathrm{C}$ for 3 days were extracted, saponified and esterified, followed by GC analysis of the fatty acid methyl esters according to the instructions of the MIDI system (Sasser, 1997). This work was performed at the Bioresources Center for Research and Collection (BCRC), Food Industry Research and Development Institute, Taiwan. DNA G + C content was determined by HPLC analysis (Shieh \& Liu, 1996), which was also performed at BCRC. DNA-DNA relatedness between strains $\mathrm{TMAl}^{\mathrm{T}}$ and Thalassomonas

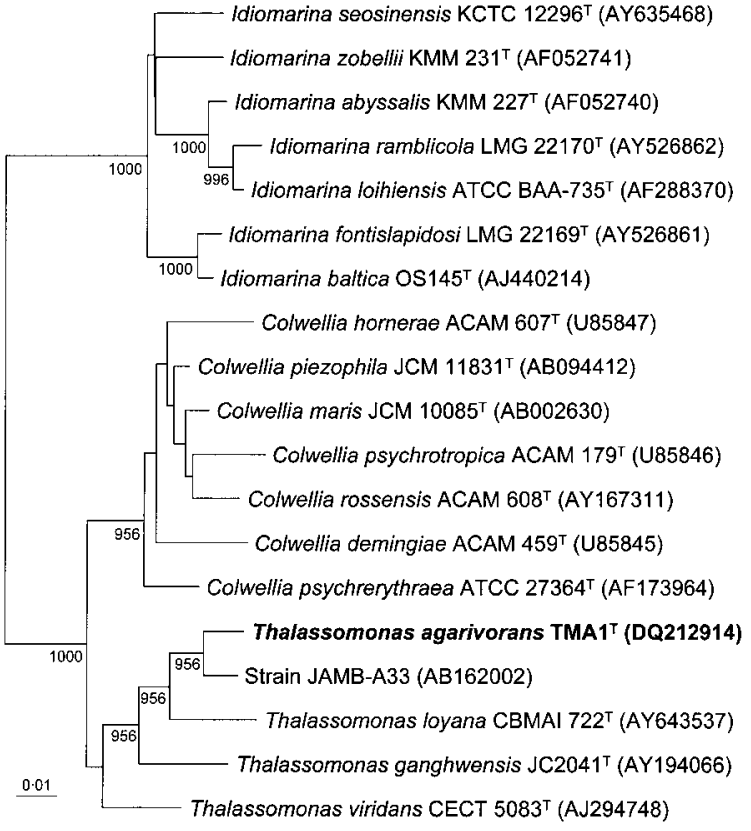

Fig. 1. Unrooted phylogenetic tree derived from neighbour-joining analysis of the $16 \mathrm{~S}$ rRNA gene sequences of strain $\mathrm{TMA}^{\top}$ and related members of the Gammaproteobacteria. GenBank accession numbers are given in parentheses. Numbers above branch nodes are bootstrap values obtained with 1000 resamplings. Bar, 0.01 nucleotide substitutions per position.

loyana CBMAI $722^{\mathrm{T}}$ was determined as described by Shieh et al. (2003a).

Growth and other phenotypic characteristics of strain $\mathrm{TMA}^{\mathrm{T}}$ were examined by the methods of Shieh et al. (2000) with modifications and additional tests as described below. Growth at different temperatures was determined in PY broth and recorded daily for up to 5 days at $20,25,30$, 35,37 and $40{ }^{\circ} \mathrm{C}$ and for 20 days at $4,10,13$ and $15^{\circ} \mathrm{C}$, unless significant growth had been observed. Growth at various $\mathrm{NaCl}$ levels was determined in PY broth containing 0, 0.5, 1 , $2,3,4,5,6,7$ or $8 \% \mathrm{NaCl}$. Anaerobic growth in PY, PYG (Polypepton/yeast extract/glucose) and PYN (Polypepton/ yeast extract/nitrate) broth media under argon gas was examined as described by Shieh et al. (2004). Utilization of various carbohydrates and other compounds as sole carbon and energy sources for growth was determined in CM (carbohydrate/mineral) media (Shieh et al., 2004) or modifications containing $0 \cdot 2 \%$ of any one of the test organic acids or amino acids used in place of the carbohydrates. The test compounds included glucose, D-arabinose, L-arabinose, cellobiose, fructose, galactose, lactose, maltose, mannose, melibiose, sucrose, trehalose, xylose, glycerol, dulcitol, inositol, mannitol, acetate, citrate, fumarate, $\beta$-hydroxybutyrate, malonate, tartrate, L-alanine, arginine, aspartate, gluconate, glutamine, glutamate, leucine, lysine, tryptophan and L-aconitate. $\mathrm{H}_{2} \mathrm{~S}$ production from thiosulphate was tested as described by Shieh et al. (2004). Urease, arginine 
dihydrolase, lysine decarboxylase, ornithine decarboxylase and hydrolysis of aesculin, alginate and lecithin were tested by methods similar to those of Smibert \& Krieg (1994): the urease test was carried out with Christensen urea agar (Smibert \& Krieg, 1994) containing $25 \mathrm{~g} \mathrm{NaCll}^{-1}$ instead of the original $5 \mathrm{~g} \mathrm{l}^{-1}$. A modified PY plate medium containing egg-yolk emulsion $\left(100 \mathrm{ml} \mathrm{l}^{-1}\right)$ was used to test the hydrolysis of lecithin. Modified plate media containing aesculin $\left(1 \mathrm{~g} \mathrm{l}^{-1}\right)$ and alginate $\left(10 \mathrm{~g} \mathrm{l}^{-1}\right)$, respectively, were used to test hydrolysis of these substrates. Tests for arginine dihydrolase, lysine decarboxylase and ornithine decarboxylase were performed in broth media containing Bacto decarboxylase base Moeller (Difco), $\mathrm{NaCl}\left(25 \mathrm{~g} \mathrm{l}^{-1}\right), \mathrm{MgCl}_{2} \cdot 6 \mathrm{H}_{2} \mathrm{O}\left(2 \mathrm{~g} \mathrm{l}^{-1}\right)$ and the appropriate L-amino acid $\left(10 \mathrm{~g} \mathrm{l}^{-1}\right)$. Other constitutive enzyme activities were detected by using the API ZYM system (bioMérieux Vitek). Cell suspensions used for these tests were prepared by suspending the cells in a mineral medium containing $0.54 \mathrm{~g} \mathrm{NH}_{4} \mathrm{Cl}, 30 \mathrm{~g} \mathrm{NaCl}, 3 \mathrm{~g}$ $\mathrm{MgCl}_{2} \cdot 6 \mathrm{H}_{2} \mathrm{O}, 2 \mathrm{~g} \mathrm{~K}_{2} \mathrm{SO}_{4}, 0.2 \mathrm{~g} \mathrm{~K}_{2} \mathrm{HPO}_{4}, 0.01 \mathrm{~g} \mathrm{CaCl}_{2}$, $0.006 \mathrm{~g} \mathrm{FeCl} 3.6 \mathrm{H}_{2} \mathrm{O}, 0.005 \mathrm{~g} \mathrm{Na} \mathrm{MoO}_{4} .7 \mathrm{H}_{2} \mathrm{O}, 0.004 \mathrm{~g}$ $\mathrm{CuCl}_{2} \cdot 2 \mathrm{H}_{2} \mathrm{O}$ and $6 \mathrm{~g}$ Tris base dissolved in $1000 \mathrm{ml}$ deionized water and adjusted to $\mathrm{pH} 8 \cdot 0$. Antibiotic susceptibility tests were performed by disc-diffusion methods as described in our previous reports (Shieh et al., 2003a, b). All test cultures were incubated aerobically at $25^{\circ} \mathrm{C}$ in the dark for 7 days, unless stated otherwise.

An almost-complete 16S rRNA gene sequence of strain $\mathrm{TMA1}^{\mathrm{T}}$ (1465 bp) was determined. The sequence was aligned and compared with all bacterial sequences available in the GenBank database. Phylogenetic analysis of the $16 \mathrm{~S}$ rRNA gene sequences revealed that strain $\mathrm{TMAl}^{\mathrm{T}}$ was a member of the Alteromonas-like bacteria in the Gammaproteobacteria. The strain showed highest sequence similarities to strain JAMB-A33 $(98 \cdot 2 \%)$, T. loyana CBMAI $722^{\mathrm{T}}$ $(97 \cdot 0 \%)$, Thalassomonas ganghwensis $\mathrm{JC}^{2041^{\mathrm{T}}}(95 \cdot 2 \%)$ and Thalassomonas viridans CECT $5083^{\mathrm{T}}(94 \cdot 7 \%)$; strain JAMBA33 has not been classified on the basis of phenotypic and chemotaxonomic features. Besides members of Thalassomonas, species of Colwellia were the closest relatives of strain $\mathrm{TMA1}^{\mathrm{T}}(93 \cdot 2-93 \cdot 8 \%$ sequence similarity). No other known bacteria shared more than $91 \%$ sequence similarity with strain TMA1 ${ }^{\mathrm{T}}$. The phylogenetic tree derived from neighbourjoining analysis indicated that strains $\mathrm{TMAl}^{\mathrm{T}}$ and JAMBA33 formed a separate taxon in the genus Thalassomonas, which was supported by a bootstrap value of $100 \%$ (Fig. 1). Similar results were obtained from maximum-likelihood and maximum-parsimony algorithms (not shown).

Strain $\mathrm{TMAl}^{\mathrm{T}}$ contained $\mathrm{C}_{16: 0}$ as the most abundant fatty acid $(17 \cdot 5 \%)$. Other major fatty acids present at levels greater than $5 \%$ included $\mathrm{C}_{17: 1} \omega 8 c(12 \cdot 8 \%), \mathrm{C}_{17: 0}$ $(11 \cdot 1 \%), \mathrm{C}_{15: 0}$ iso $2-\mathrm{OH} / \mathrm{C}_{16: 1} \omega 7 c(8 \cdot 6 \%$; the MIDI system could not differentiate these two fatty acids) and $\mathrm{C}_{13: 0}$ (7·3\%). T. ganghwensis (Yi et al., 2004) and T. viridans (Macián et al., 2001a) were also found to contain abundant $\mathrm{C}_{15: 0}$ iso $2-\mathrm{OH} / \mathrm{C}_{16: 1} \omega 7 c(20 \cdot 6-28 \cdot 4 \%)$ and $\mathrm{C}_{16: 0}(13 \cdot 7-$ $22 \cdot 3 \%)$. However, $\mathrm{C}_{17: 0}$ and $\mathrm{C}_{13: 0}$ were present at low levels
$(0-4 \cdot 7 \%)$ or were not detectable in these species. Strain $\mathrm{TMAl}^{\mathrm{T}}$ was rather different from $T$. loyana (Thompson et al., 2006) in the proportions of $\mathrm{C}_{13: 0}(7 \cdot 3 \mathrm{vs} 1 \cdot 2 \%), \mathrm{C}_{14: 0}$ ( $4 \cdot 7$ vs $13 \cdot 1 \%), \mathrm{C}_{15: 0}$ iso $2-\mathrm{OH} / \mathrm{C}_{16: 1} \omega 7 c(8 \cdot 6$ vs $31 \cdot 3 \%)$, $\mathrm{C}_{16: 0}(17 \cdot 5$ vs $4 \cdot 6 \%)$ and $\mathrm{C}_{17: 0}(11 \cdot 1$ vs $0 \%)$. Other differences in cellular fatty acids between strain $\mathrm{TMAl}^{\mathrm{T}}$ and Thalassomonas species are shown in Table 1.

Strain $\mathrm{TMAl}^{\mathrm{T}}$ had a DNA G $+\mathrm{C}$ content of $41 \cdot 0 \mathrm{~mol} \%$, similar to $T$. ganghwensis $(42.0 \mathrm{~mol} \%)$ and $T$. loyana $(39 \cdot 3 \mathrm{~mol} \%)$ but significantly lower than $T$. viridans $(48 \cdot 4 \mathrm{~mol} \%)$. The DNA-DNA relatedness value of strains $\mathrm{TMAl}^{\mathrm{T}}$ and T. loyana CBMAI $722^{\mathrm{T}}$ was $24 \cdot 6 \%$, when genomic DNA of the former strain was used as a probe. The two strains could be classified as two different genomic species according to this result.

Strain $\mathrm{TMA1}^{\mathrm{T}}$ grew significantly over a $\mathrm{pH}$ range of 7-9, with better growth at $\mathrm{pH} 8-9$. No growth could be observed below $\mathrm{pH}$ 6. It grew over a temperature range of $20-35^{\circ} \mathrm{C}$ and most rapidly at $25^{\circ} \mathrm{C}$. Growth was relatively slow and weak at 15 and $37^{\circ} \mathrm{C}$ and absent at 4,13 and $40^{\circ} \mathrm{C}$. The strain was halophilic, growing in $1-5 \% \mathrm{NaCl}$, with optimal

Table 1. Cellular fatty acids (\%) of strain $\mathrm{TMA}^{\top}{ }^{\top}, T$. viridans, $T$. ganghwensis and T. loyana

Strains: 1, strain $\mathrm{TMAl}^{\mathrm{T}}$ (data from this study); 2, T. viridans CECT $5083^{\mathrm{T}}$ and CECT 5082 (Macián et al., 2001a); 3, T. ganghwensis $\mathrm{JC}^{2041^{\mathrm{T}}}$ (Yi et al., 2004); 4, T. loyana CBMAI $722^{\mathrm{T}}$ (Thompson et al., 2006). -, Not detected; tr, trace amount detected $(<1 \%)$.

\begin{tabular}{|c|c|c|c|c|}
\hline Fatty acid & 1 & 2 & 3 & 4 \\
\hline $\mathrm{C}_{10: 0}$ & $1 \cdot 1$ & $\operatorname{tr}$ & $4 \cdot 9$ & - \\
\hline $\mathrm{C}_{11: 0}$ & $2 \cdot 2$ & $\operatorname{tr}-1 \cdot 1$ & - & - \\
\hline $\mathrm{C}_{12: 0}$ & $4 \cdot 8$ & $1 \cdot 6-2 \cdot 0$ & - & $2 \cdot 3$ \\
\hline $\mathrm{C}_{11: 0} 3-\mathrm{OH}$ & $1 \cdot 4$ & $3 \cdot 0-4 \cdot 2$ & - & $2 \cdot 5$ \\
\hline $\mathrm{C}_{13: 0}$ iso & $1 \cdot 3$ & - & - & - \\
\hline $\mathrm{C}_{13: 0}$ & $7 \cdot 3$ & $\operatorname{tr}$ & - & $1 \cdot 2$ \\
\hline $\mathrm{C}_{12: 0} 3-\mathrm{OH}$ & $2 \cdot 2$ & $5 \cdot 0-6 \cdot 1$ & - & $6 \cdot 3$ \\
\hline $\mathrm{C}_{14: 0}$ iso & $1 \cdot 2$ & - & - & - \\
\hline $\mathrm{C}_{14: 0}$ & $4 \cdot 7$ & $2 \cdot 3-3 \cdot 1$ & - & $13 \cdot 1$ \\
\hline $\mathrm{C}_{15: 1}$ iso $\mathrm{H} / \mathrm{C}_{13: 0} 3-\mathrm{OH}$ & $2 \cdot 8$ & $\operatorname{tr}-1 \cdot 3$ & - & - \\
\hline $\mathrm{C}_{15: 1} \omega 8 c$ & $2 \cdot 7$ & $4 \cdot 5-5 \cdot 8$ & - & $3 \cdot 1$ \\
\hline $\mathrm{C}_{14: 0} 3-\mathrm{OH} / \mathrm{C}_{16: 1}$ iso $\mathrm{I}$ & $2 \cdot 0$ & - & - & - \\
\hline $\mathrm{C}_{16: 0}$ iso & $\operatorname{tr}$ & $\operatorname{tr}$ & $7 \cdot 1$ & - \\
\hline $\mathrm{C}_{16: 1} \omega 9 c$ & $2 \cdot 9$ & - & $4 \cdot 7$ & $5 \cdot 7$ \\
\hline $\mathrm{C}_{15: 0}$ iso $2-\mathrm{OH} / \mathrm{C}_{16: 1} \omega 7 c$ & $8 \cdot 6$ & $21 \cdot 2-28 \cdot 4$ & $20 \cdot 6$ & $31 \cdot 3$ \\
\hline $\mathrm{C}_{15: 0}$ & - & $6 \cdot 0-11 \cdot 1$ & $1 \cdot 2$ & - \\
\hline $\mathrm{C}_{16: 0}$ & $17 \cdot 5$ & $11 \cdot 2-13 \cdot 7$ & $22 \cdot 3$ & $4 \cdot 6$ \\
\hline $\mathrm{C}_{17: 1} \omega 8 c$ & $12 \cdot 8$ & $14 \cdot 1-19 \cdot 7$ & $4 \cdot 4$ & $11 \cdot 7$ \\
\hline $\mathrm{C}_{17: 0}$ & $11 \cdot 1$ & $3 \cdot 1-4 \cdot 7$ & - & - \\
\hline $\mathrm{C}_{18: 1} \omega 9 c$ & $2 \cdot 3$ & $\operatorname{tr}$ & - & $1 \cdot 9$ \\
\hline $\mathrm{C}_{18: 1} \omega 7 c$ & $4 \cdot 8$ & $3 \cdot 2-6 \cdot 1$ & $11 \cdot 3$ & $6 \cdot 6$ \\
\hline $\mathrm{C}_{18: 0}$ & $1 \cdot 7$ & $\operatorname{tr}$ & - & - \\
\hline
\end{tabular}


growth at $3 \% \mathrm{NaCl}$; no growth was observed at 0 or $6-8 \%$ $\mathrm{NaCl}$. Substitution of $\mathrm{KCl}(1-5 \%)$ for $\mathrm{NaCl}$ did not support growth, indicating that the strain required $\mathrm{Na}^{+}$for growth and that the $\mathrm{Na}^{+}$requirement was not for osmotic function. Strain TMA1 ${ }^{\mathrm{T}}$ exhibited good growth in PY, PYN and PYG broth media under aerobic conditions (maximal $\mathrm{OD}_{600}>0 \cdot 6$ ), whereas no growth was observed in these media under anaerobic conditions. This indicated that the strain was a strict aerobe that could not achieve anaerobic growth by either nitrate reduction or glucose fermentation. Various marine bacteria have been reported to grow in CM media and their modifications containing carbohydrates, organic acids or amino acids as sole carbon and energy sources (Shieh et al., 2000, 2003a, b, 2004). Strain TMA1 ${ }^{\mathrm{T}}$ might require organic growth factors, since it did not grow in any of these media, nor did it grow significantly in any of these media supplemented with Bacto yeast extract at $0 \cdot 1 \mathrm{~g} \mathrm{l}^{-1}$ (maximal $\mathrm{OD}_{600}<0 \cdot 05$ ).

Strain $\mathrm{TMAl}^{\mathrm{T}}$ was Gram-negative. It produced circular, offwhite, opaque and non-luminescent colonies surrounded by distinct depressions on PY agar plates after incubation for $2-5$ days. Clear yellow haloes formed around the colonies in contrast to the purple-brown background when the plates were flooded with iodine/potassium iodide solution. This indicated diffusion of agarase out from the colonies and release of reducing compounds during agar hydrolysis. Cells grown in PY broth were straight or curved rods, non-motile and non-flagellated during the late exponential to early stationary phase of growth. Carbohydrate fermentation tests in PYC (Polypepton/yeast extract/carbohydrate) stab media (Shieh et al., 2000) indicated that the strain did not ferment any of the test carbohydrates D-arabinose, L-arabinose, cellobiose, galactose, glucose, lactose, mannose, melibiose, sucrose, trehalose and xylose. Oxidase and catalase tests were both positive. Indole was not produced from tryptophan. Aesculin, alginate, casein, DNA, gelatin and starch were hydrolysed, but lecithin and Tween 80 were not. Nitrate was reduced to nitrite but not further to $\mathrm{N}_{2} \mathrm{O}$ or $\mathrm{N}_{2}$. Additional phenotypic characterization data are given below in the species description.

Strain $\mathrm{TMA}^{\mathrm{T}}$ was phenotypically distinguished from $T$. ganghwensis (Yi et al., 2004), T. viridans (Macián et al., 2001a) and T. loyana (Thompson et al., 2006) in that it was a non-motile, non-flagellated bacterium capable of decomposing agar. Other characteristics useful for differentiating strain $\mathrm{TMAl}^{\mathrm{T}}$ from these Thalassomonas species are summarized in Table 2.

Phylogenetic, chemotaxonomic and phenotypic data accumulated in this study support the establishment of a novel species in the genus Thalassomonas. The name Thalassomonas agarivorans is proposed for this novel species, with $\mathrm{TMAl}^{\mathrm{T}}$ as the type strain. Establishment of this novel species requires an emended description of the genus Thalassomonas, since the genus is currently defined as including only motile, polar-flagellated species that are incapable of nitrate reduction and hydrolysis of agar and alginate.
Table 2. Characteristics that differentiate strain $T M A 1^{\top}$ from $T$. viridans, $T$. ganghwensis and $T$. loyana

Strains: 1, strain $\mathrm{TMAl}^{\mathrm{T}}$ (data from this study); 2, T. viridans CECT $5083^{\mathrm{T}}$ and CECT 5082 (Macián et al., 2001a); 3, T. ganghwensis $\mathrm{JC}^{2041^{\mathrm{T}}}$ (Yi et al., 2004); 4, T. loyana CBMAI $722^{\mathrm{T}}$ (Thompson et al., 2006). +, Positive; -, negative; W, weakly positive; ND, no data available. All species grow at $16-36^{\circ} \mathrm{C}$ and in $2-5 \% \mathrm{NaCl}$, are positive for catalase and are negative for arginine dihydrolase, lysine decarboxylase and ornithine decarboxylase.

\begin{tabular}{|lcccc|}
\hline Characteristic & $\mathbf{1}$ & $\mathbf{2}$ & $\mathbf{3}$ & $\mathbf{4}$ \\
\hline Colony colour & Off-white & Green & Yellow & Cream \\
Motility & - & + & + & + \\
Monotrichous flagellation & - & + & + & + \\
Oxidase & + & + & + & - \\
Growth in/at: & & & & \\
$1 \% \mathrm{NaCl}$ & + & - & + & + \\
$6 \% \mathrm{NaCl}$ & - & + & + & + \\
$8 \% \mathrm{NaCl}$ & - & - & + & + \\
$13{ }^{\circ} \mathrm{C}$ & - & + & - & - \\
$40{ }^{\circ} \mathrm{C}$ & - & - & + & - \\
Hydrolysis of: & & & & \\
Aesculin & + & $\mathrm{ND}$ & + & + \\
Agar & + & - & - & - \\
Alginate & + & - & - & + \\
Lecithin & - & + & - & $\mathrm{ND}$ \\
Starch & + & + & - & + \\
Tween 80 & - & - & + & - \\
Nitrate reduction & + & - & + & $\mathrm{W}$ \\
API ZYM tests: & & & & \\
Esterase lipase (C8) & + & $\mathrm{ND}$ & - & $\mathrm{ND}$ \\
Valine arylamidase & - & $\mathrm{ND}$ & + & $\mathrm{ND}$ \\
$\alpha$-Chymotrypsin & + & $\mathrm{ND}$ & - & $\mathrm{ND}$ \\
$\alpha$-Glucosidase & + & $\mathrm{ND}$ & - & $\mathrm{ND}$ \\
$\quad N-$ Acetyl- $\beta$-glucosaminidase & + & $\mathrm{ND}$ & - & $\mathrm{ND}$ \\
DNA G+C content $(\mathrm{mol} \%)$ & $41 \cdot 0$ & $48 \cdot 4$ & $42 \cdot 0$ & $39 \cdot 3$ \\
& & & & \\
\hline
\end{tabular}

\section{Emended description of the genus Thalassomonas Macián et al. 2001}

Thalassomonas (Tha.las'so.mo.nas. Gr. fem. n. thalassa the sea; Gr. n. monas a unit; N.L. fem. n. Thalassomonas a monad from the sea).

Members are Gram-negative rods belonging to the Gammaproteobacteria. Catalase-positive. Oxidase is usually present. Non-motile or motile by means of a single polar flagellum. Halophilic, growing in $2-4 \% \mathrm{NaCl}$ but not in the absence of $\mathrm{NaCl}$. Mesophilic, growing at $20-35^{\circ} \mathrm{C}$ but not at 4 or $45^{\circ} \mathrm{C}$. Chemo-organotrophs capable of respiratory but not fermentative metabolism. Arginine dihydrolase, lysine decarboxylase and ornithine decarboxylase are absent. Cells contain either $\mathrm{C}_{15: 0}$ iso $2-\mathrm{OH} / \mathrm{C}_{16: 1} \omega 7 \mathrm{cor} \mathrm{C}_{16: 0}$ as the most abundant fatty $\operatorname{acid}(\mathrm{s})$. The DNA G $+\mathrm{C}$ content is $39 \cdot 3-$ $48.5 \mathrm{~mol} \%$. The type species is Thalassomonas viridans. 


\section{Description of Thalassomonas agarivorans sp. nov.}

Thalassomonas agarivorans (a.ga.ri.vo'rans. N.L. n. agarum agar; L. part. adj. vorans devouring, destroying; N.L. part. adj. agarivorans agar-devouring).

In addition to the characteristics included in the emended description of the genus, the following characteristics are observed. Cells during late exponential to early stationary phase of growth in broth cultures are non-motile, straight or curved rods that measure approximately $1 \cdot 4-2 \cdot 2$ by $0 \cdot 4-$ $0 \cdot 7 \mu \mathrm{m}$. Colonies produced on agar plates are circular, offwhite, opaque, non-luminescent and agarolytic; distinct depressions are formed by these colonies in a few days and much of the agar in the plate medium is liquefied after incubation for several weeks. Growth occurs between 15 and $37^{\circ} \mathrm{C}$ with optimal growth at $25^{\circ} \mathrm{C}$; no growth at $4-13$ or $40{ }^{\circ} \mathrm{C}$. Growth occurs in $1-5 \% \mathrm{NaCl}$ with optimal growth at $3 \%$; no growth at 0 or $6 \% \mathrm{NaCl}$. Able to grow over a $\mathrm{pH}$ range of 7-9 but not at $\mathrm{pH} 6$. Nitrate is reduced to nitrite but not further to $\mathrm{N}_{2} \mathrm{O}$ or $\mathrm{N}_{2} . \mathrm{H}_{2} \mathrm{~S}$ is not produced from thiosulphate. Indole is not produced from tryptophan. Aesculin, alginate, casein, DNA, gelatin and starch are hydrolysed but lecithin, Tween 80 and urea are not. The following constitutive enzyme activities are detected in API ZYM tests: $\alpha$-chymotrypsin, esterase (C4), esterase lipase (C8), $N$-acetyl- $\beta$-glucosaminidase, $\alpha$-glucosidase, leucine arylamidase, naphthol-AS-BI-phosphohydrolase, acid phosphatase and alkaline phosphatase. Organic growth factors are probably required since growth does not occur on the following compounds as sole carbon sources: glucose, D-arabinose, L-arabinose, cellobiose, fructose, galactose, lactose, maltose, mannose, melibiose, sucrose, trehalose, xylose, glycerol, dulcitol, inositol, mannitol, acetate, citrate, fumarate, $\beta$-hydroxybutyrate, malonate, tartrate, L-alanine, arginine, aspartate, gluconate, glutamine, glutamate, leucine, lysine, tryptophan and L-aconitate. Cellular fatty acids present at levels greater than $5 \%$ include $\mathrm{C}_{16: 0}, \mathrm{C}_{17: 1} \omega 8 c$, $\mathrm{C}_{17: 0}, \mathrm{C}_{15: 0}$ iso 2-OH/C $16: 1 \omega 7 c$ and $\mathrm{C}_{13: 0}$. Susceptible to ampicillin $(10 \mu \mathrm{g})$, colistin $(10 \mu \mathrm{g})$, erythromycin $(15 \mu \mathrm{g})$, gentamicin $(10 \mu \mathrm{g})$, kanamycin $(30 \mu \mathrm{g})$, neomycin $(30 \mu \mathrm{g})$, novobiocin $(30 \mu \mathrm{g})$, penicillin $\mathrm{G}(10 \mathrm{U})$, polymyxin $\mathrm{B}$ $(300 \mathrm{U})$ and tetracycline $(30 \mu \mathrm{g})$; intermediate susceptibility to nalidixic acid $(30 \mu \mathrm{g})$; resistant to carbenicillin $(100 \mu \mathrm{g})$, cephalothin $(30 \mu \mathrm{g})$, chloramphenicol $(30 \mu \mathrm{g})$, clindamycin $(2 \mu \mathrm{g})$, lincomycin $(2 \mu \mathrm{g})$, oxacillin $(1 \mu \mathrm{g})$, streptomycin $(10 \mu \mathrm{g})$ and vancomycin $(30 \mu \mathrm{g})$.

The type strain, $\mathrm{TMAl}^{\mathrm{T}}\left(=\mathrm{BCRC} 17492^{\mathrm{T}}=\mathrm{JCM} 13379^{\mathrm{T}}\right)$, was isolated from shallow seawater of An-Ping Harbour, Tainan, Taiwan. It has a DNA G + C content of $41 \cdot 0 \mathrm{~mol} \%$.

\section{Acknowledgements}

We are very grateful to Dr J.-S. Chen, School of Medicine, China Medical University, Taiwan, for advice and critical reading of the manuscript. This work was supported by grants NSC94-2313-B-002066 and NSC93-2218-E-426-003 from the National Science Council.

\section{References}

Agbo, J. A. C. \& Moss, M. O. (1979). The isolation and characterization of agarolytic bacteria from a low-land river. J Gen Microbiol 115, 355-368.

Akagawa-Matsushita, M., Matsuo, M., Koga, Y. \& Yamasato, K. (1992). Alteromonas atlantica sp. nov. and Alteromonas carrageenovora sp. nov., bacteria that decompose algal polysaccharides. Int J Syst Bacteriol 42, 621-627.

Felsenstein, J. (1981). Evolutionary trees from DNA sequences: a maximum likelihood approach. J Mol Evol 17, 368-376.

Felsenstein, J. (1985). Confidence limits on phylogenies: an approach using the bootstrap. Evolution 35, 22-33.

Fitch, W. M. (1971). Toward defining the course of evolution: minimum change for a specific tree topology. Syst Zool 20, 406-416.

Gauthier, G., Gauthier, M. \& Christen, R. (1995). Phylogenetic analysis of the genera Alteromonas, Shewanella, and Moritella using genes coding for small-subunit rRNA sequences and division of the genus Alteromonas into two genera, Alteromonas (emended) and Pseudoalteromonas gen. nov., and proposal of twelve new species combinations. Int J Syst Bacteriol 45, 755-761.

Holt, J. G., Krieg, N. R., Sneath, P. H., Staley, J. T. \& Williams, S. T. (editors) (1994). Bergey's Manual of Determinative Bacteriology, 9th edn. Baltimore: Williams \& Wilkins.

Ivanova, E. P., Flavier, S. \& Christen, R. (2004). Phylogenetic relationships among marine Alteromonas-like proteobacteria: emended description of the family Alteromonadaceae and proposal of Pseudoalteromonadaceae fam. nov., Colwelliaceae fam. nov., Shewanellaceae fam. nov., Moritellaceae fam. nov., Ferrimonadaceae fam. nov., Idiomarinaceae fam. nov. and Psychromonadaceae fam. nov. Int J Syst Evol Microbiol 54, 1773-1788.

Jean, W. D., Shieh, W. Y. \& Chiu, H.-H. (2006). Pseudidiomarina taiwanensis gen. nov., sp. nov., a marine bacterium isolated from shallow coastal water of An-Ping Harbour, Taiwan, and emended description of the family Idiomarinaceae. Int J Syst Evol Microbiol 56, 899-905.

Macián, M. C., Ludwig, W., Schleifer, K. H., Garay, E. \& Pujalte, M. J. (2001a). Thalassomonas viridans gen. nov., sp. nov., a novel marine $\gamma$-proteobacterium. Int J Syst Evol Microbiol 51, 1283-1289.

Macián, M. C., Ludwig, W., Schleifer, K. H., Pujalte, M. J. \& Garay, E. (2001b). Vibrio agarivorans sp. nov., a novel agarolytic marine bacterium. Int J Syst Evol Microbiol 51, 2031-2036.

Ohta, Y., Hatada, Y., Miyazaki, M., Nogi, Y., Ito, S. \& Horikoshi, K. (2005). Purification and characterization of a novel alpha-agarase from a Thalassomonas sp. Curr Microbiol 50, 212-216.

Romanenko, L. A., Zhukova, N. V., Rhode, M., Lysenko, A. M., Mikhailov, V. V. \& Stackebrandt, E. (2003a). Pseudoalteromonas agarivorans sp. nov., a novel marine agarolytic bacterium. Int J Syst Evol Microbiol 53, 125-131.

Romanenko, L. A., Zhukova, N. V., Rhode, M., Lysenko, A. M., Mikhailov, V. V. \& Stackebrandt, E. (2003b). Glaciecola mesophila sp. nov., a novel marine agar-digesting bacterium. Int J Syst Evol Microbiol 53, 647-651.

Sasser, M. (1997). Identification of bacteria by gas chromatography of cellular fatty acids. MIDI Technical Note 101. Newark, DE: MIDI.

Shieh, W. Y. \& Jean, W. D. (1998). Alterococcus agarolyticus gen. nov., sp. nov., a halophilic thermophilic bacterium capable of agar degradation. Can J Microbiol 44, 637-645.

Shieh, W. Y. \& Liu, C. M. (1996). Denitrification by a novel halophilic fermentative bacterium. Can J Microbiol 42, 507-514.

Shieh, W. Y., Simidu, U. \& Maruyama, Y. (1988). Nitrogen-fixation by marine agar-degrading bacteria. J Gen Microbiol 134, 1821-1825. 
Shieh, W. Y., Chen, A.-L. \& Chiu, H.-H. (2000). Vibrio aerogenes sp. nov., a facultatively anaerobic, marine bacterium that ferments glucose with gas production. Int J Syst Evol Microbiol 50, 321-329.

Shieh, W. Y., Chen, Y.-W., Chaw, S.-M. \& Chiu, H.-H. (2003a). Vibrio ruber sp. nov., a red, facultatively anaerobic, marine bacterium isolated from sea water. Int J Syst Evol Microbiol 53, 479-484.

Shieh, W. Y., Jean, W. D., Lin, Y.-T. \& Tseng, M. (2003b). Marinobacter lutaoensis sp. nov., a thermotolerant marine bacterium isolated from a coastal hot spring in Lutao, Taiwan. Can J Microbiol 49, 244-252.

Shieh, W. Y., Lin, Y.-T. \& Jean, W. D. (2004). Pseudovibrio denitrificans gen. nov., sp. nov., a marine, facultatively anaerobic, fermentative bacterium capable of denitrification. Int J Syst Evol Microbiol 54, 2307-2312.

Skerratt, J. H., Bowman, J. P. \& Nichols, P. D. (2002). Shewanella olleyana sp. nov., a marine species isolated from a temperate estuary which produces high levels of polyunsaturated fatty acids. Int J Syst Evol Microbiol 52, 2101-2106.
Smibert, R. M. \& Krieg, N. R. (1994). Phenotypic characterization. In Manual of Methods for General and Molecular Bacteriology, pp. 607-654. Edited by P. Gerhardt. Washington, DC: American Society for Microbiology.

Thompson, F. L., Barash, Y., Sawabe, T., Sharon, G., Swings, J. \& Rosenberg, E. (2006). Thalassomonas loyana sp. nov., a causative agent of the white plague-like disease of corals on the Eilat coral reef. Int J Syst Evol Microbiol 56, 365-368.

van der Meulen, H. J., Harder, W. \& Veldkamp, H. (1974). Isolation and characterization of Cytophaga flevensis sp. nov., a new agarolytic flexibacterium. Antonie van Leeuwenhoek 40, 329-346.

von Hofsten, B. \& Malmqvist, M. (1975). Degradation of agar by a Gram-negative bacterium. J Gen Microbiol 87, 150-158.

Yi, H., Bae, K. S. \& Chun, J. (2004). Thalassomonas ganghwensis sp. nov., isolated from tidal flat sediment. Int J Syst Evol Microbiol 54, 377-380. 